\title{
Profil Status Vitamin D, Aktivitas Fisik dan Kesehatan Paru pada Tukang Bangunan
}

\author{
Amelia Lorensia $^{1^{*}}$, Rivan Virlando Suryadinata ${ }^{2}$, Ni Luh Mitha Rini Chandra ${ }^{3}$ \\ ${ }^{1,3}$ Fakultas Farmasi, Universitas Surabaya, Surabaya \\ ${ }^{2}$ Fakultas Kedokteran, Universitas Surabaya, Surabaya
}

\begin{abstract}
ABSTRAK
Tukang bangunan memiliki kecenderungan terpapar polusi udara yang menurunkan fungsi paru. Vitamin D merupakan salah satu faktor yang erat kaitannya dengan gaya hidup seseorang, termasuk juga aktifitas fisik yang dapat meningkatkan fungsi paru dan vitamin $\mathrm{D}$. Tujuan penelitian ini adalah untuk mengetahui profil vitamin $\mathrm{D}$, aktivitas fisik, dan kesehatan paru pada tukang bangunan. Penelitian ini dilakukan di bulan September 2018-Januari 2019, yang berlokasi di Surabaya Timur. Metode yang digunakan dalam penelitian ini menggunakan teknik pengumpulan data dengan kuesioner untuk mengukur status vitamin D dan aktivitas fisik. Sedangkan pengukuran fungsi paru dengan mengukur nilai rasio FEV1/FVC (forced expiratory volume in the first one second to the forced vital capacity) dengan menggunakan spirometri. Sampel penelitian adalah tukang becak tanpa gangguan pernafasan. Analisa data yang digunakan adalah deskriptif dengan menggunakan profil status vitamin D, aktifitas fisik dan kondisi fungsi paru. Sebagian besar responden mengalami defisiensi vitamin D sebanyak 120 orang $(75,95 \%)$. Responden sebagian besar juga memiliki aktivitas fisik yang berat $(48,73 \%)$. Sedangkan terkait kesehatan paru, sebanyak $50 \%$ orang tidak memiliki gangguan fungsi paru, dan ada sebagian yang mengalami gangguan paru ringan $(37,34 \%)$ dan berat $(12,66 \%)$. Kesimpulan penelitian ini adalah tukang bangunan berisiko mengalami defisiensi vitamin D dan gangguan fungsi paru, walaupun memiliki tingkat aktifitas fisik yang berat.
\end{abstract}

Kata kunci: aktivitas fisik; FEV/FVC; status vitamin D; tukang bangunan

\begin{abstract}
Introduction: Construction workers tend to be exposed to air pollution which reduces lung function. Vitamin D is a factor that is closely related to a person's lifestyle. Including physical activity can improve lung function and vitamin D. Aim of study: This study aims to determine the profile of vitamin D, physical activity, and lung health in builders. Method: This research was conducted in September 2018-January 2019, which is located in East Surabaya. This study used a data collection technique with a questionnaire to measure vitamin D status and physical activity. Meanwhile, the measurement of lung function is by measuring the value of the FEVI / FVC (forced expiratory volume in the first one second to the forced vital capacity) ratio using spirometry. The research sample was a pedicab driver without respiratory problems. The data analysis used is descriptive using profiles of vitamin D status, physical activity, and lung function conditions. Results and discussion: The majority of respondents experienced vitamin $D$ deficiency as many as 120 people (75.95\%). Most of the respondents also had heavy physical activity (48.73\%). Meanwhile, regarding lung health, as many as 50\% of people do not have lung function disorders, and some have mild (37.34\%) and severe (12.66\%) lung disorders. Conclusion: Construction workers are at risk for vitamin D deficiency and pulmonary function disorders, despite having a heavy level of physical activity.
\end{abstract}

Keywords: physical activity; FEV / FVC; vitamin D status; construction workers

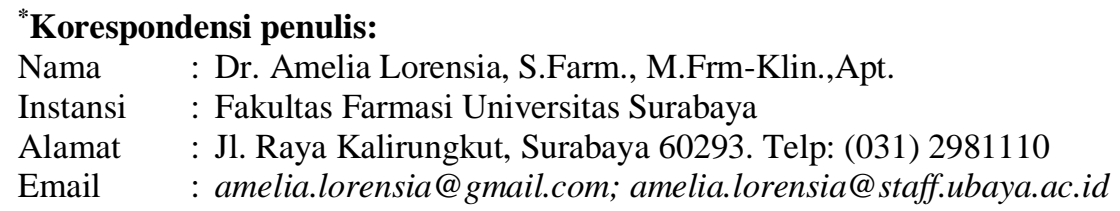




\section{Pendahuluan}

Tukang bangunan adalah salah satu jenis pekerjaan yang rentan terkena gangguan pernapasan dikarenakan lingkungan kerja yang banyak terpapar debu konstruksi. Mayoritas pekerjaan yang berisiko mengalami gangguan pernapasan adalah pekerjaan yang kesehariannya terpapar oleh debu, seperti tukang bangunan, buruh pabrik dan penambang emas. ${ }^{1,2}$ Semua lokasi konstruksi menghasilkan tingkat debu yang tinggi (biasanya dari beton, semen, kayu, batu, silika) dan ini dapat dibawa untuk jarak yang jauh selama jangka waktu yang panjang. Debu pada pembangunan diklasifikasikan sebagai PM10 atau partikel dengan diameter kurang dari 10 mikron dan tidak dapat dilihat oleh mata secara langsung dan dapat menembus jauh ke dalam paru-paru dan menyebabkan berbagai masalah kesehatan seperti penyakit pernapasan, asma, bronchitis, dan bahkan kanker. ${ }^{3,4}$ Polusi udara yang semakin tinggi, khususnya di daerah perkotaan sering kali menjadi pemicu terjadinya gangguan pernapasan. ${ }^{5}$ Gangguan ini menyebabkan angka morbitas yang tinggi. Gangguan pernapasan mengakibatkan ketidakmampuan penderita melakukan aktivitas sehari-hari, hilangnya produktivitas, dan menurunnya kualitas hidup, kesemuanya semakin memburuk sejalan dengan bertambah parahnya penyakit. ${ }^{6}$

Gangguan pernapasan juga terjadi karena disebabkan oleh beberapa faktor seperti polusi, merokok, obesitas, dan status sosial ekonomi masyarakat. Umumnya suatu penyakit saluran pernapasan dimulai dengan keluhan-keluhan dan gejala-gejala yang ringan. Inhalasi asap rokok dan partikel berbahaya lainnya menyebabkan inflamasi di saluran napas dan paru. ${ }^{7}$

Indonesia merupakan daerah tropis sehingga masyarakat mudah terpapar sinar matahari yang merupakan salah satu sumber terbesar vitamin D karena vitamin D dapat disintesis dari tubuh dengan bantuan sinar matahari. Sinar matahari adalah sumber vitamin D yang bisa ditemukan secara alami dan gratis. Sinar matahari mengandung vitamin D hingga $80 \%{ }^{8,9}$ Tetapi, masyarakat di Indonesia banyak yang menggunakan pelindung tubuh seperti jaket, topi, payung, tabir surya saat berpergian dengan alasan untuk melindungi kulit dari paparan sinar matahari sehingga ada kemungkinan kekurangan vitamin D. ${ }^{10,11,12,13}$

Kekurangan vitamin D dikaitkan dengan sejumlah penyakit pernapasan, dengan efek pada infeksi pernapasan dan fungsi paru-paru. Suplementasi dengan vitamin D tampaknya meningkatkan banyak kondisi paru-paru. Ada hubungan antara vitamin $\mathrm{D}$ dan penyakit paru kronis, Data menunjukkan hubungan yang signifikan antara defisiensi vitamin $\mathrm{D}$ dan penurunan tes fungsi paru pada rawat jalan besar populasi. Penyakit paru-paru kronis seperti asma dan penyakit paru obstruktif kronik (PPOK) juga dikaitkan dengan vitamin $\mathrm{D}$ secara genetik. Pengaruh imun dan genetik dari vitamin D ini dapat mempengaruhi patogenesis penyakit paruparu kronis. . $^{14,15}$

Tingkat vitamin D pada setiap orang diyakini bervariasi karena sejumlah alasan, termasuk asupan makanan, aktivitas fisik dan paparan sinar matahari. Faktor risiko lain untuk tingkat vitamin $\mathrm{D}$ bervariasi termasuk jenis kelamin, usia, status sosial ekonomi dan penyalahgunaan tembakau. ${ }^{12}$ Aktivitas fisik adalah setiap gerakan tubuh yang dihasilkan oleh otot rangka yang memerlukan pengeluaran energi. Aktivitas fisik yang tidak ada (kurangnya aktivitas fisik) merupakan salah satu dari faktor risiko penyakit kronis, dan secara keseluruhan diperkirakan menyebabkan kematian secara global. Vitamin D dan aktivitas fisik berpengaruh baik terhadap absorbsi kalsium. Vitamin D berfungsi dalam pertumbuhan tulang normal dan proses mineralisasi. Vitamin $D$ juga mempengaruhi metabolisme kalsium. Vitamin ini dapat disintesis di kulit, ada beberapa faktor yang membatasi produksi vitamin D seperti peningkatan pigmentasi di kulit dan tabir surya. Dengan adanya proses penuaan terjadi penurunan kapasitas produksi vitamin D di kulit. Perubahan tulang yang disebabkan oleh aktivitas fisik dapat meningkatkan enzim tulang dan pembesaran pada tulang. ${ }^{16,17,18}$ Berdasarkan latar belakang diatas, maka tujuan penelitian ini adalah untuk 
mengetahui profil vitamin $\mathrm{D}$, aktivitas fisik, dan kesehatan paru pada tukang bangunan.

\section{Metode}

Desain yang akan digunakan dalam penelitian ini adalah cross-sectional. Penelitian ini dilakukan di bulan September 2018-Januari 2019, yang berlokasi di Surabaya Timur. Penelitian ini menggunakan teknik pengumpulan data dengan kuesioner untuk mengukur status vitamin $\mathrm{D}$ dan aktivitas fisik. Sedangkan pengukuran fungsi paru dengan mengukur nilai rasio FEV1/FVC (forced expiratory volume in the first one second to the forced vital capacity) dengan menggunakan spirometer merk Contec ${ }^{T M}$ model SP10 yang sudah tervalidasi. Gangguan fungsi paru adalah kondisi dimana nilai rasio FEV1/FVC $<70 \%$.

Parameter pengukuran kuesioner status vitamin $D$ yang dikutip dari penelitian sebelumnya, ${ }^{16,17}$ yang terdiri dari 15 pertanyaan yang berisi tentang paparan sinar matahari, berapa lama mendapatkan paparan sinar matahari, alat pelindung dari sinar matahari, penggunaan tabir surya, kosmetik yang mengandung SPF, konsumsi ikan,telur, susu, serta suplemen vitamin $\mathrm{D}$, tanda dan gejala vitamin D. data yang dihasilkan berupa data ordinal dengan mengkategorikan defisiensi vitamin D dan cukup vitamin D. Dikatakan defisiensi vitamin D bila nilai total jawaban dari kuesioner $\leq 8$ dan dikatakan cukup vitamin $\mathrm{D}$ bila nilai total jawaban dari kuesioner $>8$.

Pada penelitian ini, metode untuk mengukur aktivitas fisik menggunakan kuesioner, yaitu IPAQ (International Physical Activity Questionaire) yang telah dimodifikasi. ${ }^{18}$ Kuesioner ini berisikan pertanyaan tentang jenis aktivitas durasi dan frekuensi seseorang melakukan aktivitas fisik dalam jangka waktu 7 hari terakhir. Pengukuran aktivitas fisik bisa dilakukan dengan mengukur banyaknya energi yang dikeluarkan/dibutuhkan pada setiap menit kegiatan, dengan klasifikasi ringan $(<600$ METmenit/minggu); sedang (600-3000 MET- menit/minggu); dan berat (>3000 METmenit/minggu).

Populasi yang digunakan pada penelitian ini yaitu tukang bangunan yang sedang bekerja dalam proyek atau aktif di wilayah Surabaya. Sampel adalah bagian dari populasi yang memenuhi: laki-laki, perokok, berusia 18-60 tahun, telah bekerja minimal 5 tahun, tidak memiliki gangguan pernafasan kronis/ginjal/hepar. Analisis data dalam penelitian ini menggunakan deskriptif dengan menjabarkan profil status vitamin $\mathrm{D}$, aktifitas fisik dan kondisi fungsi paru.

\section{Hasil dan Pembahasan}

Tabel 1. Distribusi Frekuensi Karakteristik Responden Penelitian

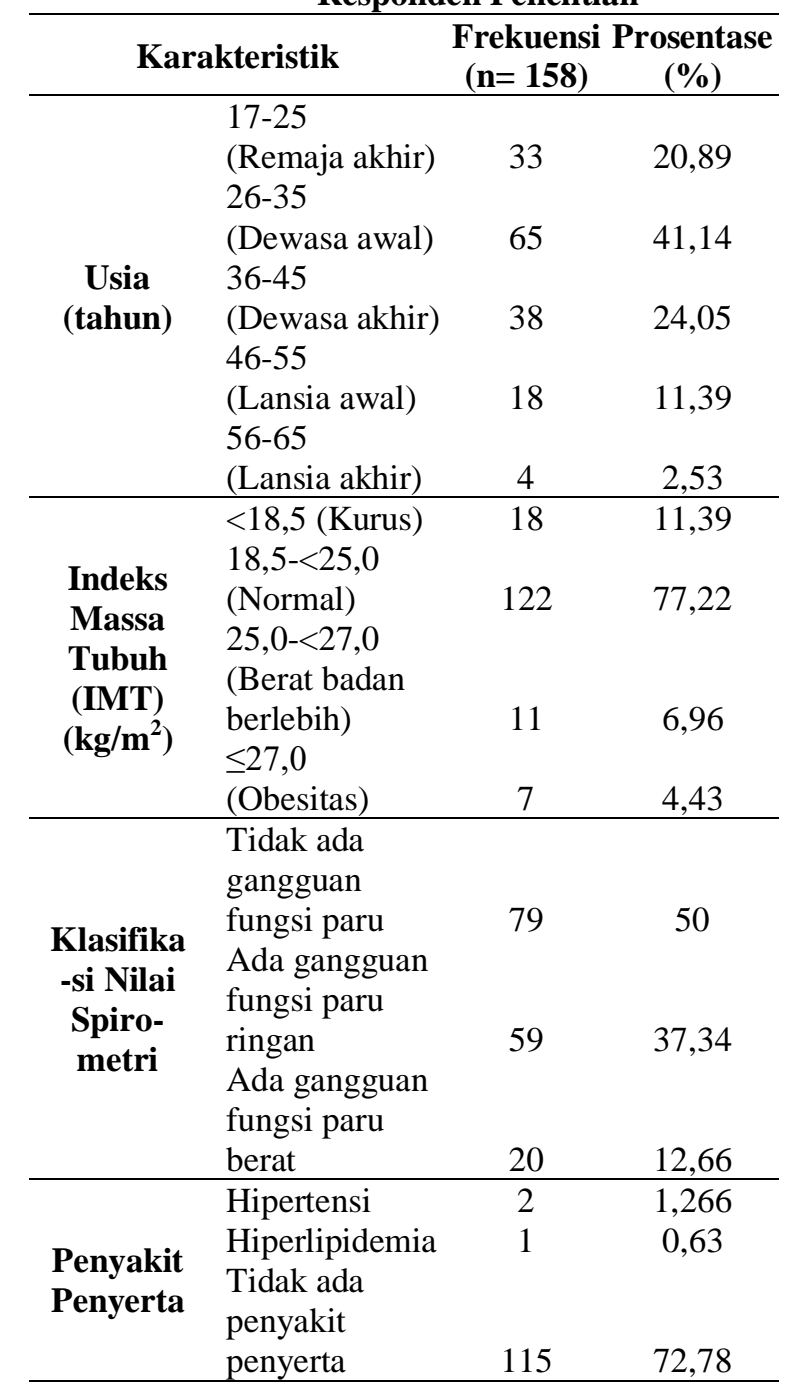


Tabel 2. Profil Status Vitamin D Responden

\begin{tabular}{|c|c|c|c|c|}
\hline \multirow[b]{2}{*}{ No. } & \multirow[b]{2}{*}{$\begin{array}{c}\text { Pertanyaan } \\
\text { Pilihan Jawaban }\end{array}$} & & \multicolumn{2}{|c|}{ Responden } \\
\hline & & & $\begin{array}{c}\text { Frekuensi } \\
(n=158)\end{array}$ & $\begin{array}{l}\text { Persentase } \\
\quad(\%)\end{array}$ \\
\hline \multirow[t]{4}{*}{1.} & \multirow{4}{*}{$\begin{array}{l}\text { Pukul berapa biasanya anda mendapatkan paparan } \\
\text { sinar matahari secara langsung? }\end{array}$} & $07.00-09.00$ & 92 & 57,86 \\
\hline & & $10.00-11.00$ & 40 & 25,16 \\
\hline & & $12.00-14.00$ & 25 & 15,72 \\
\hline & & $15.00-17.00$ & 1 & 0,63 \\
\hline \multirow[t]{2}{*}{2.} & \multirow{2}{*}{$\begin{array}{l}\text { Apakah anda menggunakan alat pelindung kulit } \\
\text { (payung, topi, jaket, krim tabir surya dll) dari paparan } \\
\text { sinar matahari secara langsung? }\end{array}$} & ya & 123 & 77,36 \\
\hline & & tidak & 35 & 22,01 \\
\hline \multirow[t]{2}{*}{3.} & \multirow[t]{2}{*}{ Alat pelindung kulit apa yang anda gunakan? } & topi & 123 & 77,36 \\
\hline & & tidak pakai & 35 & 22,01 \\
\hline \multirow[t]{3}{*}{4.} & \multirow{3}{*}{$\begin{array}{l}\text { Seberapa sering anda menggunakan alat pelindung } \\
\text { kulit pada pertanyaan no } 3 \text { ? }\end{array}$} & setiap hari & 99 & 62,26 \\
\hline & & kadang-kadang & 24 & 15,09 \\
\hline & & tidak pernah & 35 & 22,013 \\
\hline \multirow[t]{2}{*}{5.} & \multirow{2}{*}{$\begin{array}{l}\text { Apakah anda biasa menggunakan pakaian tertutup } \\
\text { seperti menggunakan baju berlengan panjang dan } \\
\text { celana panjang setiap hari? }\end{array}$} & ya & 119 & 74,84 \\
\hline & & tidak & 39 & 24,53 \\
\hline \multirow[t]{3}{*}{6.} & \multirow{3}{*}{$\begin{array}{l}\text { Bagian tubuh mana saja yang hendak anda lindungi } \\
\text { dari paparan sinar matahari langsung dengan alat } \\
\text { pelindung yang menjadi pilihan anda pada } \\
\text { pertanyaan no } 3 \text { ? }\end{array}$} & wajah & 98 & 61,64 \\
\hline & & seluruh tubuh & 25 & 15,72 \\
\hline & & tidak pernah & 35 & 22,01 \\
\hline \multirow[t]{2}{*}{7.} & \multirow{2}{*}{$\begin{array}{l}\text { Apakah anda menggunakan produk kosmetik } \\
\text { (pelembab wajah, krim tangan dan tubuh (body } \\
\text { cream), bedak dlldengan kandungan SPF? }\end{array}$} & ya & 30 & 18,99 \\
\hline & & tidak & 129 & 81,65 \\
\hline \multirow[t]{2}{*}{8.} & \multirow{2}{*}{$\begin{array}{l}\text { Apakah kosmetik yang anda gunakan mengandung } \\
\text { perlindungan dari UVA dan UVB? }\end{array}$} & ya & 30 & 18,99 \\
\hline & & tidak & 129 & 81,65 \\
\hline \multirow[t]{2}{*}{9.} & \multirow{2}{*}{$\begin{array}{l}\text { Apakah dalam seminggu terakhir ini, anda } \\
\text { mengkonsumsi ikan? }\end{array}$} & ya & 117 & 74,05 \\
\hline & & tidak & 41 & 25,95 \\
\hline \multirow[t]{2}{*}{10.} & \multirow{2}{*}{$\begin{array}{l}\text { Apakah dalam seminggu terakhir ini, anda } \\
\text { mengkonsumsi susu? }\end{array}$} & ya & 65 & 41,14 \\
\hline & & tidak & 93 & 58,86 \\
\hline \multirow[t]{2}{*}{11.} & \multirow{2}{*}{$\begin{array}{l}\text { Apakah dalam seminggu terakhir ini, anda } \\
\text { mengkonsumsi telur? }\end{array}$} & ya & 137 & 86,71 \\
\hline & & tidak & 21 & 13,29 \\
\hline \multirow[t]{2}{*}{12.} & \multirow[t]{2}{*}{ Apakah anda mengkonsumsi minyak ikan? } & ya & 11 & 6,96 \\
\hline & & tidak & 147 & 93,04 \\
\hline \multirow[t]{2}{*}{13.} & \multirow[t]{2}{*}{ Apakah anda mengkonsumsi suplemen? } & ya & 6 & 3,80 \\
\hline & & tidak & 152 & 96,21 \\
\hline
\end{tabular}

Responden dalam penelitian ini dikelompokkan berdasarkan karakteristik usia, indeks massa tubuh, klasifikasi nilai spirometri dan penyakit peserta (Tabel 1). Sedangkan profil status Vitamin D dijelaskan secara deskriptif pada tabel 2 berdasarkan isi kuesioner. Selanjutnya pada tabel 3 dan tabel 4 dijelaskan tentang rata-rata profil jawaban kuesioner status Vitamin D dan aktifitas fisik responden.

Fungsi paru dipengaruhi oleh usia. Risiko penurunan fungsi paru semakin besar seiring dengan bertambahnya usia. Semakin bertambah usia maka akan dapat menurunkan kapasitas vital paru seseorang. ${ }^{19,20}$ Usia mempengaruhi kecukupan vitamin D karena penuaan mengurangi aktivitas fisik diluar ruangan sehingga kurangnya paparan sinar matahari, adanya penurunan sintesis dan asupan makanan yang rendah. ${ }^{21,22}$ Kecukupan vitamin D yang dibutuhkan oleh usia dewasa adalah sebesar $15 \mu \mathrm{g} /$ hari. Usia merupakan salah satu faktor yang mempengaruhi kebutuhan kalori seseorang. Kebutuhan kalori pada masa bayi lebih besar dari orang dewasa, dan orang tua memerlukan lebih sedikit kalori dibandingkan orang muda atau remaja. Hal tersebut disebabkan karena pada bayi 
dan remaja terjadi peningkatan kebutuhan kalori untuk menunjang percepatan tumbuh kembang. ${ }^{23,24}$

Usia juga mempengaruhi aktivitas fisik karena faktor usia diketahui tidak memiliki pengaruh yang signifikan terhadap tingkat aktivitas fisik karena perilaku aktivitas fisik sangat tergantung pada kebiasaan yang telah ditanamkan sebelumnya. ${ }^{25}$ IMT dapat mempengaruhi fungsi paru terutama nilai FVC menurun pada individu dengan obesitas. Hal ini disebabkan karena posisi diafragma pada rongga toraks naik ketika berat badan meningkat. Perubahan posisi tersebut mengakibatkan terjadinya penurunan nilai fungsi paru. Akumulasi lemak pada dinding dada akan menghambat pergerakan toraks karena terjadi fungsi yang abnormal pada otot intercostal. Penderita obesitas memiliki kadar 25(OH)D yang lebih rendah dibandingkan dengan yang tidak obesitas. Kasus obesitas berperan dalam peningkatan prevalensi dari defisiensi $25(\mathrm{OH}) \mathrm{D}$ serum pada saat ini. Rendahnya konsentrasi kadar 25(OH)D serum disebabkan karena meningkatnya serum $25(\mathrm{OH}) \mathrm{D}$ yang diserap dalam jaringan lemak, peningkatan basal metabolik, dan gaya hidup dari penderita obesitas yang cenderung kurang menyukai aktifitas di luar rumah serta kurangnya paparan sinar matahari. ${ }^{26}$ Penyebab lain dari rendahnya kadar $25(\mathrm{OH}) \mathrm{D}$ serum pada penderita obesitas adalah kadar lemak yang tinggi menyebabkan bioavailabilitas vitamin D menurun dan kadar 25(OH)D serum terdeteksi rendah di dalam darah. ${ }^{27}$

Tabel 3. Rata-rata Profil Jawaban Kuesioner Status Vitamin D Pada Responden

\begin{tabular}{ccccc}
\hline Kategori & $\begin{array}{c}\text { Jumlah } \\
\text { Responden }\end{array}$ & \multicolumn{3}{c}{ Nilai Status Vitamin } \\
\cline { 3 - 5 } & & $\begin{array}{c}\text { Rata- } \\
\text { rata }\end{array}$ & $\begin{array}{c}\text { Nilai } \\
\text { Min }\end{array}$ & $\begin{array}{c}\text { Nilai } \\
\text { Maks }\end{array}$ \\
\hline $\begin{array}{c}\text { Defisiensi } \\
(<8)\end{array}$ & 120 & & & \\
$\begin{array}{c}\text { Cukup } \\
(\geq 8)\end{array}$ & 38 & 7,59 & 1 & 13 \\
Total & 158 & & & \\
\hline
\end{tabular}

Tabel 4. Profil Aktivitas Fisik Responden

\begin{tabular}{|c|c|c|c|}
\hline Pertanyaan & $\begin{array}{c}\text { Jumlah } \\
\text { Responden }\end{array}$ & $\begin{array}{l}\text { Rata-rata } \\
\text { MET- } \\
\text { menit/ } \\
\text { minggu }\end{array}$ & $(\%)$ \\
\hline $\begin{array}{l}\text { Mengangkat } \\
\text { semen }\end{array}$ & 124 & 1713,36 & 78,48 \\
\hline $\begin{array}{l}\text { Mengangkat } \\
\text { kayu }\end{array}$ & 111 & 1717,35 & 70,25 \\
\hline Menangkat batu & 124 & 1713,36 & 78,48 \\
\hline Mengecat & 59 & 1684,32 & 37,34 \\
\hline $\begin{array}{l}\text { Membongkar } \\
\text { bangunan }\end{array}$ & 71 & 1719 & 44,94 \\
\hline $\begin{array}{l}\text { Mengangkat } \\
\text { gallon }\end{array}$ & 133 & 1713,36 & 84,18 \\
\hline $\begin{array}{l}\text { Berjalan kaki } \\
>100 \text { meter }\end{array}$ & 136 & 1714,945 & 86,08 \\
\hline Menyapu & 95 & 1693,825 & 60,13 \\
\hline Mencuci & 111 & 1714,945 & 70,25 \\
\hline Memasak & 78 & 1711,79 & 49,37 \\
\hline $\begin{array}{l}\text { Membawa } \\
\text { kendaraan } \\
\text { (sepeda, sepeda } \\
\text { motor) }\end{array}$ & 66 & 1710,505 & 41,77 \\
\hline $\begin{array}{l}\text { Membakar } \\
\text { sampah }\end{array}$ & 122 & 1712,085 & 77,23 \\
\hline
\end{tabular}

Tabel 5. Profil Kategori Tingkat Aktivitas Fisik Responden

\begin{tabular}{ccc}
\hline $\begin{array}{c}\text { Kategori } \\
\text { (MET- } \\
\text { menit/minggu) }\end{array}$ & $\begin{array}{c}\text { Jumlah } \\
\text { Responden } \\
\text { (n= 158) }\end{array}$ & $(\boldsymbol{\%})$ \\
\hline Berat & 77 & 48,73 \\
Sedang & 74 & 46,84 \\
Ringan & 7 & 4,43 \\
\hline
\end{tabular}

Berbagai teknik dapat dilakukan untuk mengukur tingkat aktivitas fisik seseorang. Instrumen standar yang digunakan adalah teknik double-labeled water. Walaupun demikian teknik ini sulit dilakukan sehingga disusun berbagai jenis teknik alternatif meliputi self-report questionnaires (IPAQ-S), accelerometry dan pedometry. Penggunaan self-report questionnaires (IPAQ-S) memiliki keunggulan yaitu biaya yang murah, tidak membebankan responden, dan mendapatkan alur aktivitas fisik yang responden lakukan. Metode self-report questionnaires (IPAQ-S) juga memiliki kelemahan yaitu memiliki akurasi dan reliabilitas yang tendah, karena data yang didapatkan berdasarkan ingatan dari responden. Pada penelitian ini pengukuran aktivitas fisik tidak dilakukan dengan accelerometry karena ketidak 


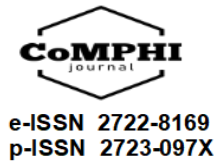

mempuan mengukur aktivitas fisik yang bervariasi. Penelitian ini juga tidak menggunakan pedometry karena pedometry hanya terbatas pada aktivitas fisik berjalan kaki.

Keterbatasan pada penelitian ini adalah ada faktor yang tidak bisa dikendalikan seperti genetik, tingkat kategori perokok. IMT tidak dapat dikendalikan tetapi tidak berpengaruh pada hasil penelitian, jenis paparan. Faktor yang bisa dikendalikan adalah usia, jenis kelamin, perokok dan polusi. Berbagai pengaruh saat pengukuran nilai fungsi paru seperti merokok, makan besar, melakukan aktivitas fisik berat sebelum pengukuran dilakukan. Pada saat pengukuran nilai fungsi paru menggunakan spirometri ada beberapa responden yang tidak mematuhi persyaratan seperti: Tidak melakukan aktivitas berat minimal 30 jam sebelum wawancara, tidak boleh merokok minimal 1 jam sebelum wawancara dimulai, tidak makan berat minimal 2 jam sebelum wawancara, karena dapat mempengaruhi pengukuran berat badan. Pengukuran fungsi paru pada penelitian ini hanya berdasarkan spirometri, sedangkan untuk mendapat hasil pengukuran fungsi yang tepat perlu juga dilakukan pengukuran volume paru, kapasitas difusi paru, dan tes olahraga.

\section{Kesimpulan}

Sebagian besar responden mengalami defisiensi vitamin D sebanyak 120 orang (75,95\%). Responden sebagian besar juga memiliki aktivitas fisik yang berat $(48,73 \%)$. Sedangkan terkait kesehatan paru, sebanyak 50\% orang tidak memiliki gangguan fungsi paru, dan ada sebagian yang mengalami gangguan paru ringan $(37,34 \%)$ dan berat $(12,66 \%)$.

\section{Ucapan Terima Kasih}

Para peneliti mengucapkan terima kasih atas dukungan Hibah LPPM Universitas Surabaya.

\section{Referensi}

1. Fishwick D, Sen D, Barber C, Bradshaw L, Robinson E, Sumner J. The COPD Standard Collaboration Group, Occupational chronic obstructive pulmonary disease: a standard of care. Occupational Medicine [Internet]. 2015 Jun [cited 2020 Sept 10];65(4):270282. Available from: https://doi.org/10.1093/occmed/kqv019.

2. Nwibo AN, Ugwuja EI, Nwambeke NO, et al. Pulmonary Problems among Quarry Workers of Stone Crushing Industrial Site at Umuoghara, Ebonyi State, Nigeria. The International Journal of Occupational and Environmental Medicine [Internet]. 2012 Oct [cited 2020 Sept 10];3:178-185. Available from: https://pubmed.ncbi.nlm.nih.gov/23022868/

3. Liu SK, Cai S, Chen Y, Xiao B, Chen P, Xiang XD. The effect of pollutional haze on pulmonary function. $\mathrm{J}$ Thorac Dis. [Internet]. 2016 Jan [cited 2020 Sept 10];8(1):E41-E56. Available from: https://dx.doi.org/10.3978\%2Fj.issn.20721439.2016.01.18.

4. Xing YF, Xu YH, Shi MH, Lian YX. The impact of PM2.5 on the human respiratory system. J Thorac Dis. [Internet]. 2016 Jan [cited 2020 Sept 10];8(1):E69-E74. Available from: https://doi.org/10.3978/j.issn.20721439.2016.01.19.

5. Jiang XQ, Mei XD, Feng D. Air pollution and chronic airway diseases: what should people know and do?. J Thorac Dis. [Internet]. 2016 Jan [cited 2020 Sept 10];8(1):E31-E40. Available from: https://doi.org/10.3978/j.issn.20721439.2015.11.50.

6. Qureshi H, Sharafkhaneh A, Hanania NA. Chronic obstructive pulmonary disease exacerbations: latest evidence and clinical implications. Ther Adv Chronic Dis. [Internet]. 2014 Sep [cited 2020 Sept 10];5(5):212-227. Available from: https://dx.doi.org/10.1177\%2F2040622314 532862.

7. Strzelak A, Ratajczak A, Adamiec A, Feleszko W. Tobacco Smoke Induces and Alters Immune Responses in the Lung Triggering Inflammation, Allergy, Asthma 
and Other Lung Diseases: A Mechanistic Review. Int J Environ Res Public Health [Internet]. 2018 May [cited 2020 Sept 10];15(5):1033. Available from: https://dx.doi.org/10.3390\%2Fijerph150510 33.

8. Nair R, Maseeh A. Vitamin D: The "sunshine" vitamin. J Pharmacol Pharmacother [Internet]. 2012 May [cited 2020 Sept 10];3(2):118-126. Available from:

https://www.jpharmacol.com/text.asp?2012 /3/2/118/95506.

9. Wacker M, Holick MF. Sunlight and Vitamin D: A global perspective for health. Dermatoendocrinol. [Internet]. 2013 Jan [cited 2020 Sept 10];5(1):51-108. Available from: https://doi.org/10.4161/derm.24494.

10. Lorensia A, Suryadinata RV, Fitrianingsih N. 2020. Knowledge of Sunlight Exposure Toward Obesity in Geriatric. Farmasains [Internet]. 2020 [cited 2020 Sept 10];5(1):13-22. Available from: https://doi.org/10.4103/0976-500X.95506.

11. Suryadinata RV, Lorensia A, Wahyuningtyas D. Studi Tingkat pengetahuan mengenai Vitamin D pada Pengemudi Becak di Surabaya. CoMPHI Journal. 2020 [cited 2020 Sept 10];1(1):1521. Available from: https://doi.org/10.37148/comphijournal.v1i 1.4.

12. Lorensia A, Raharjo DN, Gandawari N. Pengaruh Pengetahuan-Sikap mengenai Vitamin D terkait Obesitas pada Mahasiswa. Jurnal Ilmiah Ibnu Sina [Internet]. 2020 Mar [cited 2020 Sept 10];5(1):72-86. Available from: https://doi.org/10.36387/jiis.v5i1.388.

13. Suryadinata RV, Lorensia A. Food Frequency, Knowledge about Vitamin D and Obesity among Elderly. Amerta Nutrition [Internet]. 2020 [cited 2020 Sept 10];4(1):43-48. Available from: http://dx.doi.org/10.20473/amnt.v4i1.2020. 43-48.
14. García de Tena J, El Hachem Debek A, Hernández Gutiérrez C, Izquierdo Alonso JL. Papel de la vitamina D en enfermedad pulmonar obstructiva crónica, asma y otras enfermedades respiratorias. Arch Bronconeumol. [Internet]. 2014 [cited 2020 Sept 10];50:179-184. Available from: https://www.archbronconeumol.org/en-pdfS1579212914001050.

15. Hejazi ME, Modarresi-Ghazani F, EntezariMaleki T. A review of Vitamin D effects on common respiratory diseases: Asthma, chronic obstructive pulmonary disease, and tuberculosis. J Res Pharm Pract. [Internet]. 2016 Feb [cited 2020 Sept 10];5(1):7-15. Available from: https://doi.org/10.4103/2279042X.176542.

16. Suryadinata RV, Wirjatmadi B, Andriani M, Lorensia A. Effect of Age and Weight on Physical Activity. Journal of Publich Health Research [Internet]. 2020 Jul [cited 2020 Sept 10];9(2):187-190. Available from: https://dx.doi.org/10.4081\%2Fjphr.2020.18 40

17. Suryadinata RV, Lorensia A, Tangkilisan EC. Effect of Physical Activity and Vitamin D Status on Geriatrics Obesity. Global Medical \& Health Communication [Internet]. 2019 [cited 2020 Sept 10];7(1): 1$6 . \quad$ Available from: https://ejournal.unisba.ac.id/index.php/gmh c/article/view/2916.

18. Lorensia A, Suryadinata RV, Saputra R. 2019. Physical Activity and Vitamin D Level in Asthma and Non-Asthma. Jurnal Farmasi Indonesia [Internet]. 2019 May [cited 2020 Sept 10];11(1):454-465. Available from: https://doi.org/10.35617/jfi.v11i1.591.

19. Ishii M, Yamaguchi Y, Hamaya H. et al. Characteristics of factors for decreased lung function in elderly patients with type 2 diabetes. Sci Rep. [Internet]. 2019 Dec [cited 2020 Sept 10];9:20206. Available from: https://doi.org/10.1038/s41598-01956759-3. 
20. Thomas ET, Guppy M, Straus SE, Bell KJL, Glasziou P. Rate of normal lung function decline in ageing adults: a systematic review of prospective cohort studies. BMJ Open [Internet]. 2019 Jun [cited 2020 Sept 10];9:e028150. Available from: https://doi.org/10.1136/bmjopen-2018028150.

21. Remelli F, Vitali A, Zurlo A, Volpato S. Vitamin D Deficiency and Sarcopenia in Older Persons. Nutrients [Internet]. 2019 Nov [cited 2020 Sept 10];11(12):2861. Available from: https://doi.org/10.3390/nu11122861.

22. Spiro A, Buttriss JL. Vitamin D: An overview of vitamin D status and intake in Europe. Nutr Bull. [Internet]. 2014 Dec [cited 2020 Sept 10];39(4):322-350. Available from: https://doi.org/10.1111/nbu.12108.

23. Bundy DAP, Silva Nd, Horton S, et al., editors. Child and Adolescent Health and Development. 3rd edition. Washington (DC): The International Bank for Reconstruction and Development / The World Bank; 2017 Nov [cited 2020 Sept 10]. Available from: https://www.ncbi.nlm.nih.gov/books/NBK5 $25240 /$.

24. Zmitek K, Hribar M, Hristov H, Pravst I. Efficiency of Vitamin D Supplementation in Healthy Adults is Associated with Body Mass Index and Baseline Serum 25Hydroxyvitamin D Level. Nutrients [Internet]. 2020 Apr [cited 2020 Sept 10];12:1268. Available from: https://doi.org/10.3390/nu12051268.

25. McPhee JS, French DP, Jackson D, Nazroo J, Pendleton N, Degens H. Physical activity in older age: perspectives for healthy ageing and frailty. Biogerontology [Internet]. 2016 Jun [cited 2020 Sept 10];17(3):567-580. Available from: https://doi.org/10.1007/s10522-016-96410.

26. Vanlint S. Vitamin D and obesity. Nutrients [Internet]. 2013 Mar [cited 2020 Sept
10];5(3):949-56. Available from: https://doi.org/10.3390/nu5030949.

27. Tosunbayraktar G, Bas M, Kut A, Buyukkaragoz AH. Low serum 25(OH)D levels are associated to higher BMI and metabolic syndrome parameters in adult subjects in Turkey. Afr Health Sci. [Internet]. 2015 Dec [cited 2020 Sept 10];15(4):1161-1169. Available from: https://doi.org/10.4314/ahs.v15i4.15. 